The ANATOMY of

HARPO MARX 
The publisher gratefully acknowledges the generous support of the Ahmanson Foundation Humanities Endowment Fund of the University of California Press Foundation. 


\section{The ANATOMY of}

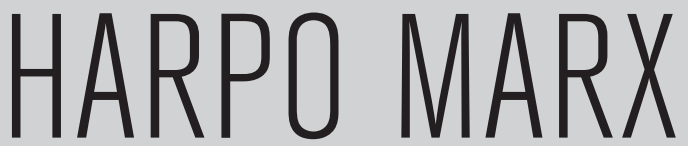

\section{WAYNE KOESTENBAUM}

甲

UNIVERSITY OF CALIFORNIA PRESS

Berkeley Los Angeles London 
University of California Press, one of the most distinguished university presses in the United States, enriches lives around the world by advancing scholarship in the humanities, social sciences, and natural sciences. Its activities are supported by the UC Press Foundation and by philanthropic contributions from individuals and institutions. For more information, visit www.ucpress.edu.

University of California Press

Berkeley and Los Angeles, California

University of California Press, Ltd.

London, England

(C) 2012 by The Regents of the University of California

Library of Congress Cataloging-in-Publication Data

Koestenbaum, Wayne.

The anatomy of Harpo Marx / Wayne Koestenbaum.

p. $\mathrm{cm}$.

ISBN 978-0-520-26900-2 (cloth : alk. paper)

ISBN 978-0-520-2690I-9 (pbk. : alk. paper)

I. Marx, Harpo, I888-I964. 2. Motion picture actors and actresses-United States-Biography. 3. Comedians-United States-Biography. I. Title. PN2287.M54K84 2012

$792.702^{\prime} 8092-\mathrm{dc} 23$

[B]

2011024490

Manufactured in the United States of America

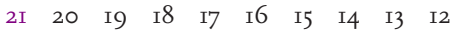
I0 $9 \begin{array}{lllllllll} & 9 & 7 & 6 & 5 & 4 & 3 & 2 & \text { I }\end{array}$

The paper used in this publication meets the minimum requirements of ANSI/ NIsO Z39.48-I992 (R I997) (Permanence of Paper). 
Any classification you read provokes a desire in you to put yourself into it somewhere: where is your place? At first you think you have found it; but gradually, like a disintegrating statue or an eroding relief, its shape blurs and fades, or better still, like Harpo Marx losing his artificial beard in the glass of water he is drinking out of, you are no longer classifiable. — ROLAND BARTHes, Roland Barthes 
This page intentionally left blank 